\title{
Avointa kirjojen julkaisutoimintaa Lontoon malliin - Suomen tiedekustantajien liiton matka Lontooseen 9.-12.4.2018
}

\author{
Heidi Enwald \\ Informaatiotutkimus, Oulun yliopisto \\ heidi.enwald@oulu.fi \\ https://orcid.org/0000-0003-1953-2157
}

Asiasanat: avoin tiede; kirja-ala; kirjamessut; kustantajat; open access

Historiallisesti kirja on esineenä ollut harvojen saatavilla ja luettavissa. Ajan saatossa kirja on muuttunut etuoikeudesta arkisemmaksi, meitä kaikkia lähellä olevaksi esineeksi ja ilmiöksi. Nykyään monista kirjoista julkaistaan paperisen ohessa myös sähköinen versio, e-kirja. E-kirjojen saatavuus on tällä hetkellä tapetilla muun muassa Suomen Kirjastoseuran lanseeraaman "Koko kansan ekirjasto" -aloitteen kautta (Suomen kirjastoseura, 2018). Aloitteen perusteluksi on nostettu alueellisen tasa-arvon edistäminen.

Tieteellisen tiedon levittämisessä kirja on tietyissä tapauksissa artikkelia parempi ratkaisu. Tutkimusta voidaan julkaista teemaa laajasti käsittelevinä teoksina tai aiheiden ympäriltä voidaan koota kokoomateoksia. Tällöinkin mahdolliset saatavilla olevat e-kirjat ovat yleensä maksullisia, ja esimerkiksi meille korkeakoulukirjastojen asiakkaille saatavissa kirjaston tietokantojen kautta.

Pelkkiin e-kirjoihin keskittyminen on julkaisukentällä vielä vähäistä. Suomessa esimerkiksi vuonna 2010 aloittanut kustannusyhtiö Kirjalabyrintti julkaisee kirjoja ainoastaan digitaalisessa muodossa (Kirjalabyrintti, 2018). Monet tieteelliset teokset julkaistaan nykyään sekä paperisena että e-kirjana ja esimerkiksi kurssien materiaaliksi korkeakoulukirjastot saattavat päätyä tilaamaan näistä juurikin e-kirjaversion. 
Monografioiden ja kokoomateosten avoin julkaiseminen on kansainvälisesti ja Suomessa vielä pienimuotoisempaa kuin tieteellisten lehtien. Tieteellisten e-kirjojen avoimuuteen liittyvä keskustelu linkittyy läheisesti yleiseen keskusteluun siitä, missä suhteessa pyrkimys avoimuuteen on julkaisemisen kuluihin. Muuttuvatko julkaisemisen vaiheet ja niihin liittyvä työ? Pienevätkö kulut? Kuka maksaa? Tiedekirjojen avoin julkaiseminen edellyttää toimivaa ansaintalogiikkaa. Keskustelua on käyty myös siitä, onko avoimesti saatavilla olevan teoksen arvostus erilaista kuin maksullisen.

\section{Sivistymässä Lontoossa}

Huomasin tiedon Suomen tiedekustantajien liiton messumatkasta heidän sähköpostitiedotteestaan. Hain ja tulin valituksi matkalle mukaan. Tunnustan, etten ollut aiheesta niin hyvin perillä, että vierailujemme tähdet olisivat olleet minulle entuudestaan tuttuja. Vierailukohteiden lisäksi osallistuimme matkalla Lontoon kirjamessuille, nautimme opastetusta kierroksesta British Libraryssa ja toistemme seurasta kello viiden teen merkeissä.

Avoin julkaiseminen on itselleni tutuinta avoimesti saatavilla olevan tieteellisen lehtemme toimituskunnassa toimimisen kautta ja toki oman tutkijanurani myötä, mutta esimerkiksi avointen tieteellisten kirjojen julkaisemisen maailma sekä monenmoiset rahoituskuviot ja muut käänteet avautuivat minulle värikkäinä ja kimurantteina vasta matkan myötä. Tätä maailmaa avasivat vierailukohteidemme University College London (UCL) Pressin edustaja Lara Speicher, Imperial College Londonin (ICL) edustaja Chris Banks ja Open Book Publishers -kustantamon edustaja Rupert Gatti. Vierailukohteissa käyntien yhteydessä käydyissä keskusteluissa minulle antoisiksi nousivat myös matkamme muiden osallistujien esittelyt, jotka avasivat Suomen eri toimijoiden tilanteita ja intressejä aiheen parista. Vierailukohteista avaan nyt erityisesti UCL Pressin ja kirjamessujen antia.

\section{University College London Press}

UCL Press (UCL, 2018) on ensimmäinen täysin avoin open access yliopistokustantamo Isossa-Britanniassa. Avoimuus tarkoittaa sitä, että sen kaikki tuotteet ovat avoimesti saatavissa, vaikka niitä voidaan myydä myös maksullisina versioina. UCL Press julkaisee tieteellisiä monografioita, editoituja kokoomateoksia, oppikirjoja sekä myös muutamia tieteellisiä lehtiä. Aihealueita ei ole rajattu. UCL päätyi ottamaan julkaisemisen omiin käsiinsä tarttuen avoimuuteen vuonna 2015. Tavoitteena on saattaa erityisesti yliopiston omien 
tutkijoiden tutkimustuloksia avoimesti kaikkien kansalaisten ja päättäjien saataville.

Käsikirjoitukset käyvät läpi tarkan arviointi- ja editointiprosessin. Julkaisutoiminta on avoinna myös muille kuin UCL:n henkilökunnalle ja tutkijoille. UCL tukee omien tutkijoidensa julkaisemista, mutta ulkopuoliselle kirjoittajalle julkaiseminen maksaa noin 5000-700o puntaa ellei kirjaa katsota niin laadukkaaksi, että sen olisi mahdollista saada erityinen etuoikeus ilmaiseen julkaisemiseen ("free waiver"). UCL Pressin tavoitteena on julkaista 50 kirjaa vuodessa. Digitaalisten versioiden lisäksi kirjat ovat saatavilla painettuina, mutta niitä myydään keskimäärin vain 100-200 kappaletta ja myynti keskittyy teoksen ensimmäiseen julkaisuvuoteen.

Digitaalisista versioista usein pelkkä PDF on ilmainen, mutta esimerkiksi ePub -versiosta joutuu maksamaan muutamia puntia. Vierailumme hetkellä ladatuin kirja oli How The World Changed Social Media (Daniel Miller et al.) vuodelta 2016. Lara Speicher kertoi meille myös UCL Pressin BOOC-mallista, joka on nähty tulevaisuuden malliksi akateemisille kirjoille. BOOC eli "Books as Open Online Content" muodossa kirja on staattisen teoksen sijaan kasvavaa ja kehittyvää verkkosisältöä.

Näin matkan jälkeen University College Londonin sivuja tarkastellessani ei voi olla huomaamatta heidän iloista 23.5. julkaistua uutistaan miljoonasta latauksesta. Onnittelut!

\section{London Book Fair}

Ennen Lontoon messuihin tutustumista sanana kirjamessut kytkeytyivät mielessäni vahvasti Helsingin kirjamessuihin. Lontoon messujen luonne ihmisten kasvokkain tapahtuvien kustannustoimintaan liittyvien tapaamisten kenttänä yllätti, vaikka ennakkokäsitystäni "kirjamessuista” olinkin saanut korjattua jo ennen matkaa. Kauniin Olympia-messukeskuksen osastot olivat tulvillaan pyöreitä pöytiä, joiden ääressä keskusteltiin, neuvoteltiin ja sovittiin mitä erinäisimmistä julkaisemiseen liittyvistä asioista. Kirjailijat kohtasivat julkaisijoita ja moni kirja löysi kodin kustantamon suojista tai päätyi käännetyksi uusille kielille.

Suomea messuilla edusti Kirjallisuuden vientikeskus FILI sijoittuen yhteispohjoismaiselle osastolle. Vuonna 1977 perustettu FILI edistää Suomen kirjallisuuden käännösten ilmestymistä maailmalla toimimalla ammattilaiskontaktien välittäjänä (FILI, 2018).

Koska omat intressini eivät liittyneet oikeuksista neuvottelemiseen, keskityin lähinnä kokonaisuuden hahmottamiseen, eri toimijoihin ja heidän tarjontaansa tutustumiseen sekä messujen paneelikeskustelutarjonnan seuraamiseen. 
Paneelikeskusteluista löytyi myös kiinnostava akateemisempi avoimeen julkaisemiseen keskittyvä linja kuunneltavaksemme.

\section{Matkan keskeisin anti}

Matkan keskeisintä antia oli lisääntynyt ymmärrykseni avoimen julkaisemisen kentästä. Monografioiden ja kokoomateosten kohdalla avoimuuteen liittyvät kysymykset ovat pitkälti samoja kuin tieteellisten lehtien kohdalla, vaikka digitaalinen avoin julkaiseminen on niihin verrattuna vielä vähäistä. Matka kirvoitti myös miettimään sitä, miten aiheita voisi ottaa esille informaatiotutkimuksen alan opetuksessa. Erityisesti tieteellisten kirjojen julkaiseminen on muutoksessa. Matkan aikana solmitut suhteet muihin osallistujiin ovat pysyneet vahvoina myös matkan jälkeen. Jopa niin että yhteistä projektiakin on muutamien kanssa päästy virittelemään liittyen suomalaisten tiedejulkaisujen ja -seurojen markkinointiin. Tästä kuulette toivottavasti lisää tulevaisuudessa!

\section{Lähteet}

FILI. (2018). Kirjallisuuden vientikeskus FILI. https://www.finlit.fi/fili/

Kirjalabyrintti. (2018). Kustannusosakeyhtiö Kirjalabyrintti. https://www.kirjalabyrintti.net/ Suomen kirjastoseura. (2018). Koko kansan e-kirjasto - miksi tarvitsemme valtakunnallisen e-kirjaston? http://suomenkirjastoseura.fi/artikkelit/koko-kansan-e-kirjasto-miksitarvitsemme-valtakunnallisen-e-kirjaston/

UCL. (2018). University College London Press. http://www.ucl.ac.uk/ucl-press 